\title{
Determinants of Care-Seeking Practices for Children with Sickle Cell Disease in Ekiti, Southwest Nigeria
}

This article was published in the following Dove Press journal:

Journal of Blood Medicine

\begin{abstract}
Oladele Simeon Olatunya $\mathbb{D}^{1,2}$ Adefunke Olarinre Babatola $\mathbb{D}^{1,2}$ Adewuyi Temidayo Adeniyi (iD) Olubunmi Adeola Lawal ${ }^{3}$ Alaba Olanrewaju Daramola ${ }^{4}$ Tosin Anthony Agbesanwa ${ }^{5}$ Temitope Olumuyiwa Ojo $\mathbb{D}^{6}$ Paul Oladapo Ajayi (iD ${ }^{7}$

Adeleke Ajayi Ibijola ${ }^{8}$ Akinwumi Kolawole Komolafe (iD) ${ }^{2}$ Adekunle Adekile ${ }^{9}$

'Department of Paediatrics, College of Medicine, Ekiti State University, Ado Ekiti, Nigeria; ${ }^{2}$ Department of Paediatrics, Ekiti State University Teaching Hospital, Ado Ekiti, Nigeria; ${ }^{3}$ Department of Paediatrics, Federal Teaching Hospital, Ido Ekiti, Ekiti State, Nigeria; ${ }^{4}$ Department of Hematology and Blood Transfusion, Ekiti State University, Ado Ekiti, Ekiti State, Nigeria;

${ }^{5}$ Department of Family Medicine, College of Medicine, Ekiti State University, Ado Ekiti, Ekiti State, Nigeria; ${ }^{6}$ Department of Community Health, Obafemi Awolowo University lle-Ife, Ile-Ife, Osun State, Nigeria; ${ }^{7}$ Department of Community Medicine, College of Medicine, Ekiti State University, Ado Ekiti, Ekiti State, Nigeria; ${ }^{8}$ Department of Hematology, Federal Teaching Hospital, Ido Ekiti/Afe Babaloa University, Ado Ekiti, Ekiti State, Nigeria; ${ }^{9}$ Department of Pediatrics, Faculty of Medicine, Kuwait University, Kuwait City, Kuwait
\end{abstract}

Correspondence: Oladele Simeon Olatunya

Department of Paediatrics, College of Medicine, Ekiti State University, Ado Ekiti,

Ekiti State, Nigeria

Tel +23480386I 7705

Email ladeletunya@yahoo.com
Background: Due to the chronic nature of sickle cell disease (SCD), affected individuals may seek help from diverse places thus raising the need to understand their health-seeking behavior (HSB) in order to design an appropriate management policy for them.

Aim: The aim of this study was to evaluate the HSB among pediatric SCD patients relative to their non-SCD counterparts attending a tertiary facility in Southwest Nigeria and identified predictors of poor HSB among SCD patients.

Methods: A total of 110 children with SCD were recruited and studied for their HSPs which were compared with 110 non-SCD patients with other chronic medical conditions. Questionnaires were used to obtain self-reported information on participants' sociodemographic data and HSB. Logistic regression was used to determine the predictors of poor HSB among the SCD cohort.

Results: More SCD patients received treatments at private hospitals, patent medicine stores and faith-based centers compared to their non-SCD counterparts $(p=0.0052 ; 0.006$; and $0.007)$, respectively. No difference was observed in the patronage of traditional care centres $10(9.1 \%)$ vs $6(5.5 \%)$. More SCD patients $61(55.5 \%)$ vs $35(31.8 \%)$ exhibited poor HSB $(\mathrm{p}=0.0004)$. SCD patients who were not enrolled on health insurance scheme were 18 times more likely to have poor HSB $(\mathrm{OR}=18.38,95 \% \mathrm{CI}(4.41-76.57)$, $\mathrm{p}$ value $=<0.0001)$ while absence of VOC within the preceding year reduces the risk of poor HSB by $91.5 \%$ $(\mathrm{OR}=0.085,95 \% \mathrm{CI}(0.028-0.258)$, $\mathrm{p}$ value $=<0.0001)$.

Conclusion: SCD patients in the study locality had poor HSB. This raises the need for their education on proper HSB. More enrollment into health insurance scheme and the prevention of VOC will lessen the burden of poor HSB. The high patronage of non-hospital care facilities in this study raises the need for stakeholders to monitor activities and train the operators at these informal care centres.

Keywords: sickle cell disease, health-seeking behavior, non-orthodox care, Nigeria

\section{Introduction}

Sickle cell disease (SCD) is an inherited blood disorder characterized by chronic anemia, acute painful episodes, and chronic organs damage. ${ }^{1,2}$ It is associated with a significant reduction in life expectancy especially in resource-poor countries with low quality of health care and weak health systems. ${ }^{1,2}$ Individuals homozygous for the sickle hemoglobin $(\mathrm{HbS})$ have sickle cell anemia (SCA), which is the most severe form of the disease spectrum. It is the most common genetic disease in sub-Saharan Africa. ${ }^{1-3}$ Globally, about 312,000 neonates are born with SCA annually, $75 \%$ of which occur in Africa. ${ }^{3}$ Nigeria has the highest burden of the disease where between $1 \%$ and $2 \%$ of newborns are born annually 
with the medical condition. ${ }^{2}$ It is also an important cause of childhood morbidity and mortality in the country. $^{2}$

The clinical manifestations of the disease are many and these include serious chronic and debilitating conditions. ${ }^{3,4,5-7}$ Due to the genetic nature and complexities of its pathophysiology, the management of SCD is also still evolving and this includes supportive and potentially curative interventions. ${ }^{4,5,7}$ However, in developing countries like Nigeria, the management and care available are still largely supportive and suboptimal. ${ }^{2,8}$ Hence, individuals affected with SCD may be left to worry about how to get help for their medical condition.

Health-seeking behavior (HSB) is defined as an action undertaken by individuals who perceive themselves as having a health problem or to be ill, for the purpose of finding an appropriate remedy or simply put, the varied response of individuals to states of ill-health, depending on their knowledge and perceptions of health, socioeconomic constraints, adequacy of available health services and attitude of healthcare providers. ${ }^{9,10}$

Being sick or having ill health is a major life event that may disrupt basic activities of life ${ }^{10}$ and what people do when they are ill has major implications for morbidity, progression and outcome of the illness. ${ }^{10}$ These include places where people seek health care and the kind of treatments sought for some of which may be inimical and harmful. Furthermore, it has been noted that people take decisions based on their respective socio-cultural, economic, demographic circumstances, disease pattern, perceived severity of the illness, attitude of health provider and organization of the health-care system. ${ }^{10-13}$

Studies have reported the involvement of non-qualified and alternative caregivers in the management of chronic diseases especially in rural areas and resource-poor countries. ${ }^{14-18}$ Similar patterns have been observed in the care of patients with SCD. ${ }^{17,19-21}$ These observations reflect that many people in Nigeria and other developing countries have strong beliefs in religious institutions and non-orthodox care centres for healing and healthcare services as people in these communities sometimes refer to children suffering from chronic medical conditions like SCD as being afflicted by spirits/devils because of the nature and clinical presentation of these diseases and as such, believe that these children need spiritual and other non-orthodox care. ${ }^{18,20}$ They may, therefore, seek miracles, and healing at some faith-based centers and other non-orthodox facilities. These findings raise the need to understand the health-seeking behavior of any target population before one can design effective and acceptable health-care services for the care of such population or group of patients.

This study examined the healthcare-seeking behavior and treatment practices of children with SCD in comparison with children with other chronic medical conditions that are not SCD attending a tertiary hospital in Southwestern Nigeria. Information from this study may assist policy makers in formulating rational policies to provide efficient, effective, acceptable, affordable and accessible healthcare services targeted at improving the health of the pediatrics sickle cell population.

\section{Patients and Methods Study Design and Setting}

This study was conducted at the pediatric hematology unit and children out-patient clinics of the Ekiti State University Teaching Hospital (EKSUTH), Ado Ekiti which is a tertiary government-owned hospital in Nigeria between March and August 2018. EKSUTH is a tertiary referral hospital for all the Primary and Secondary Health facilities in Ekiti State and neighboring towns in other adjoining States. Children with SCD alongside their counterparts with other chronic medical disease conditions/illnesses were purposively recruited serially over a 6-month period. At the EKSUTH, the pediatric hematology unit is co-joined with the pediatric oncology unit and attends to all hemato-oncological-related illnesses in which pediatric SCD cases predominate while children with other illnesses are seen in the outpatients' and other specialist clinics. The pediatric hemato-oncology unit of the hospital is headed by a pediatrician (the lead researcher) and supported by the complements of resident doctors, nurses, other medical staffs and specialists. It runs a weekly specialist clinic where predominantly SCD patients and a few other pediatric hemato-oncology cases are referred and seen. The unit also admits and treats SCD patients presenting with complications/emergencies like bone pain crisis, severe anemia, infections, stroke, etc. The pediatric hematology unit offers routine malaria prophylaxis and multivitamins supplementation. It also offers hydroxyurea therapy and chronic blood transfusion to eligible SCD patients. However, compliances with the latter two protocols are poor. There is no routine penicillin prophylaxis or transcranial doppler ultrasound screening as these are done on a case-by-case basis and only when indicated. 


\section{Sampling Method}

Purposive sampling was used to select the participants and the minimum sample size was arrived at for either group using the formula for calculating sample size for comparison of proportions $\mathrm{n}=(\mathrm{Z} \alpha / 2+\mathrm{Z} \beta) 2 *(\mathrm{p} 1(1-\mathrm{p} 1)+\mathrm{p} 2$ $(1-\mathrm{p} 2)) /(\mathrm{p} 1-\mathrm{p} 2) 2$, where $\mathrm{n}=$ minimum sample size per group. ${ }^{22}$ Given the $56.6 \%$ prevalence (P1) of use of nonorthodox care for children with epilepsy in Ibadan, Nigeria $^{23}$ and $36 \%$ prevalence (P2) of use of nonorthodox care for children SCD in Lagos, Nigeria ${ }^{24}$ and $\beta=0.20$, at $95 \%$ confidence level $Z_{\alpha / 2}$ is 1.96 for a twotailed test, the estimated sample size was 88 per group. To compensate for non-response, assuming a $10 \%$ nonresponse, the sample size per group was further calculated using the following formula:

$$
\mathrm{N}_{\mathrm{nr}=\mathrm{n}} / 1-\mathrm{n}_{\mathrm{nr}}
$$

$\mathrm{n}=$ calculated sample size for each group $=88$

$\mathrm{n}_{\mathrm{nr}}=$ non-response rate $=10 \%=0.1$

$\mathrm{N}_{\mathrm{nr}}=$ sample size per comparison group, compensated for non-response rate. ${ }^{25}$

$$
\mathrm{N}_{\mathrm{nr}=\mathrm{n}} / 1-0.1
$$

$\mathrm{N}_{\mathrm{nr}}=\mathrm{n} / 0.9 .=88 / 0.9=97$. Hence, the minimum sample size required per group was 97 . However, 110 participants were studied per group.

\section{Study Population}

All consecutive SCD patients who attended the pediatric hematology SCD clinic and whose parents gave consent to participate in the study were recruited. The controls were non-SCD children whose parents gave consent to participate in the study and attended the children hematooncology unit, out-patient clinics and other specialist clinics of the hospital within the same period for follow up of their wards chronic illnesses (diabetes-3, asthma-25, hepatitis-2, chronic kidney diseases-5, tuberculosis-5, active HIV disease-5, recurrent seizures 51 (non-febrile -31 , and febrile-20), Down syndrome-6, and childhood cancer-8). The $\mathrm{Hb}$ genotypes of the participants in both arms were determined by $\mathrm{Hb}$ electrophoresis.

However, the SCD patients also had earlier had their SCD status further confirmed by high-performance liquid chromatography (HPLC), Biorad, USA Variant II, using the Beta thalassemia short program and DNA Polymerase Chain Reaction (PCR). ${ }^{26}$

\section{Study Procedure and Data Collection}

The purpose of the study was explained to the children and their parents/caregivers after which the consents of the caregivers were obtained as appropriate. Also, patients' assents were obtained for participants aged 7 years and above as applicable. Information on each participant's health-seeking behavior was obtained with a pre-tested questionnaire. The study instrument was revised by community physicians after the pretest at the medical outpatients' clinic of the hospital to improve its quality and incorporate observations made during the preliminary study. The questionnaire was translated into Yoruba language which is the main spoken language in the locality by an expert and was administered with the assistant of resident doctors who were fluent in both the English language and the indigenous language. Information obtained through the questionnaire included the participants' socio-demographic characteristics, occupation of the parents, parents' highest level of formal education, history of previous treatments/interventions (both hospital and non-hospital based), where such treatments were given and this was used to ascertain their health-seeking behavior in the preceding 1 year prior to recruitment. For the purpose of this study, health-seeking behavior was defined as actions undertaken by caregivers/ parents for the purpose of finding a remedy to their wards' ill health or health problems. ${ }^{9,10}$ The type of place/setting, ie whether health facility (private or public hospitals) which was considered as standard orthodox care or other non-standard or non-orthodox care centres where parents/ caregivers sought treatment(s) for their wards were noted. The health-seeking behavior was considered good when treatment was received at a hospital (private or public) and poor when treatment was received at non-orthodox, ie (non-hospital setting). In addition, the medical records of the SCD patients were retrieved manually and examined to establish the clinical evolution of the patients' disease condition vis a vis the occurrence of acute and chronic lifetime disease complications for which admissions were offered, the number of admissions, as well as other details of the treatment they received at the pediatric hematology unit within the preceding year prior recruitment. The clinical evolution record and typing of disease evolution/complications such as the occurrence of vaso-occlusive crisis (VOC), ie number of severe bone pain crises that disrupt daily activities, required hospital admission and use of opioids analgesics within the preceding 1 year prior to 
recruitment, as well as other details of their disease evolution/complications were as earlier described. ${ }^{26}$ The social classes of the parents were determined according to the Oyedeji classification system using their formal educational attainment and occupation as previously described. $^{27}$

\section{Ethical Consideration}

This study was performed according to the Declaration of Helsinki on research involving human subjects. Ethical approval was obtained from the Ethics and Research Committee of the EKSUTH and written informed consent was obtained from the guardians/parents of the children (patients and controls) as well as patients' assents where applicable and they were assured of the confidentiality of their responses. Willingness to participate or not did not affect the care given to participants as all received the same standard care. Data were stored on a computer after personal identifiers had been removed and were only accessible to the research team with a password.

\section{Data Analysis}

Data were analyzed using the Statistical Package for Social Sciences (SPSS) version 25.0. Frequencies and proportions were used to summarize categorical variables. Quantitative variables were summarized using mean and standard deviation. Chi-square test and Fisher's Exact Test were used to compare health-seeking behavior between the SCD patients and their non-SCD counterparts. Furthermore, binary logistic regression was fitted to identify the determinants of poor health-seeking behavior among the SCD cohort. The determinants/predictors were selected based on the literature. ${ }^{17,24,28}$ Both the Omnibus Tests of Model Coefficients and the Hosmer-Lemeshow goodness-of-fit test were used to assess the fitness of the final model and both tests indicate the model was well fitted with the Omnibus Tests of Model Coefficients being ( $\chi 2=35.3$, $\mathrm{p}<0.0001)$ and the Hosmer-Lemeshow goodness-of-fit test at $(\chi 2=5.74, \mathrm{p}=0.57)$ respectively. The significance level was set at $\mathrm{p}$-value $<0.05$ for all tests.

\section{Results}

The study involved 110 SCD patients (107 hemoglobin SS and 3 hemoglobin SC) and 110 non-SCD (84 Hb AA and 26 $\mathrm{Hb} \mathrm{AS}$ ) patients age- and sex-matched controls. The mean ages of the SCD patients and their non-SCD counterparts were $8.39 \pm 4.49$ and $8.85 \pm 3.22$ years, respectively.

\section{Sociodemographic Characteristics of the Study Participants}

There is no difference between SCD patients and controls with regards to socioeconomic class (Table 1).

\section{Pattern of Past Treatments/Care-Seeking Practices}

More SCD patients compared to their non-SCD counterparts $66(60.0 \%)$ vs $35(31.8 \%)(\mathrm{p}<0.0001)$ received treatments at some other places in addition to treatments given at our tertiary facility. Also, more SCD patients received care at private hospitals, patent medicine stores and faith-based centers than the controls $(\mathrm{p}<0.05)$ Table 2. In addition, more SCD patients compared to their non-SCD counterparts had received blood transfusion $(\mathrm{p}=0.0002)$. Although more SCD patients tended to patronize traditional centres and received diverse treatments $10(9.1 \%)$ vs $6(5.5 \%)$; $\mathrm{p}=0.43$, both groups tended to have an equal rate of therapeutic scarifications at non-orthodox traditional places 8/10 (80\%) vs $5 / 6(83.3 \%)$. Nevertheless, the majority of the 13 participants 8/13 (62\%) who had scarifications, were SCD patients. There were no differences with respect to other nonorthodox interventions received by the participants (Table 2).

In general, more SCD patients compared to their nonSCD counterparts $61(55.5 \%)$ vs $35(31.8 \%) \quad(p=0.0004)$ exhibited poor health-seeking behavior.

\section{Admission Pattern and Rate of the SCD Cohort}

A total of 72 (65\%) SCD patients were admitted for various comorbidities and complications of their disease in the preceding 1 year. The number of admissions ranged between 1

Table I Sociodemographic Characteristics of the Study Participants

\begin{tabular}{|l|l|l|l|l|}
\hline Characteristics & & $\begin{array}{l}\text { SCD } \\
\text { Patient } \\
\text { N=I I O } \\
\text { n (\%) }\end{array}$ & $\begin{array}{l}\text { Control } \\
\text { N=I I 0 } \\
\text { n (\%) }\end{array}$ & \\
\cline { 1 - 4 } Gender & Male & $71(64.5)$ & $70(63.6)$ & \multirow{2}{*}{$0.88^{*}$} \\
\cline { 1 - 4 } & Female & $39(35.5)$ & $40(36.4)$ & \\
\hline Social class & Low & $64(58.2)$ & $63(57.3)$ & \multirow{2}{*}{$0.94^{*}$} \\
\hline & Middle & $42(38.2)$ & $42(38.2)$ & \\
\hline & Upper & $4(3.6)$ & $5(4.5)$ & \\
\hline
\end{tabular}

Note: Test statistics $=*$ Chi-Square test. Abbreviation: SCD, sickle cell disease. 
Table 2 Pattern of Past Treatments and Care-Seeking Practices of Participants

\begin{tabular}{|c|c|c|c|}
\hline Characteristics & $\begin{array}{l}\text { SCD Patients } \\
\mathrm{N}=\text { I I } 0 \\
\text { n (\%) }\end{array}$ & $\begin{array}{l}\text { Controls } \\
\mathrm{N}=\text { I I } 0 \\
\text { n (\%) }\end{array}$ & $P$ value \\
\hline \multicolumn{4}{|c|}{ General pattern of how treatment was received } \\
\hline Our Hospital: Yes & $110.0(100.0)$ & $\begin{array}{l}110.0 \\
(100.0)\end{array}$ & \\
\hline $\begin{array}{l}\text { Other places alongside } \\
\text { our hospital: Yes }\end{array}$ & $66(60.0)$ & $35(31.8)$ & \multirow[t]{2}{*}{$<0.0001 *$} \\
\hline No & $44(40.0)$ & $75(68.2)$ & \\
\hline \multicolumn{4}{|c|}{ Sites where treatment was received outside our hospital } \\
\hline aPrivate hospital: Yes & $32(29.1)$ & $15(13.7)$ & \multirow[t]{2}{*}{$0.0052 *$} \\
\hline No & $78(70.9)$ & $95(86.3)$ & \\
\hline $\begin{array}{l}\text { aPatent Medicine shop: } \\
\text { Yes }\end{array}$ & $55(50.0)$ & $35(31.8)$ & \multirow[t]{2}{*}{ 0.006* } \\
\hline No & $55(50.0)$ & $75(68.2)$ & \\
\hline${ }^{\text {a Traditional care: Yes }}$ & $10(9.1)$ & $6(5.5)$ & \multirow[t]{2}{*}{$0.437^{\dagger}$} \\
\hline No & $100(90.9)$ & $104(94.5)$ & \\
\hline${ }^{\mathrm{a}}$ Faith-based centers: Yes & $27(24.5)$ & II (9.0) & \multirow[t]{2}{*}{$0.007^{\dagger}$} \\
\hline No & $83(75.5)$ & $99(90.0)$ & \\
\hline \multicolumn{4}{|c|}{$\begin{array}{l}\text { Type of treatment/care received aside drugs (orthodox and non- } \\
\text { orthodox) within past lyear }\end{array}$} \\
\hline Blood transfusions: Yes & $51(46.4)$ & $25(22.7)$ & \multirow[t]{2}{*}{$0.0002 *$} \\
\hline No & $59(53.6)$ & $85(77.3)$ & \\
\hline Surgical operations: Yes & I (0.9) & $2(1.8)$ & \multirow[t]{2}{*}{$1.000^{\dagger}$} \\
\hline No & $109(99.1)$ & $108(98.2)$ & \\
\hline $\begin{array}{l}\text { Prayer at faith based } \\
\text { (religious) centres: Yes }\end{array}$ & $27(24.5)$ & $25(22.7)$ & \multirow[t]{2}{*}{$0.75 I^{*}$} \\
\hline No & $83(75.5)$ & $85(77.3)$ & \\
\hline $\begin{array}{l}\text { Use of biologic products } \\
\text { (herbal medicines at } \\
\text { traditional healing center): } \\
\text { Yes }\end{array}$ & $10(9.1)$ & $6(5.5)$ & \multirow[t]{2}{*}{$0.437^{\dagger}$} \\
\hline No & $100(90.9)$ & $104(94.5)$ & \\
\hline $\begin{array}{l}\text { Scarifications (at } \\
\text { traditional healing center): } \\
\text { Yes }\end{array}$ & $8(7.3)$ & $5(4.5)$ & \multirow[t]{2}{*}{$0.284^{\dagger}$} \\
\hline No & $102(92.7)$ & $105(95.5)$ & \\
\hline
\end{tabular}

Notes: Test statistics $=\nmid$ Fisher's exact test, ${ }^{*}$ Chi-Square test. ${ }^{\text {a Many individual }}$ patients received treatments at multiple places, $\mathrm{P}$ values in bold fonts indicate statistical significance.

Abbreviation: SCD, sickle cell disease. and 4 with a median of 2 (mean $1.8 \pm 0.8$ ). The commonest reason for admission was for VOC (severe bone pains) and this was among $51(70.8 \%)$ of the admitted group. Other comorbidities/complications for which the SCD cohort members were admitted are as shown in Table 3.

\section{Association Between SCD Cohort Characteristics and Their Health-Seeking Behavior}

As shown in Table 4, lack of health insurance $(\mathrm{p}<0.0001)$, belonging to low social class $(\mathrm{p}=0.012)$ and presence of VOC $(p<0.0001)$ in the preceding year were all associated with poor health-seeking behavior on Chi-Square analysis.

\section{Determinants/Predictors of Poor Health-Seeking Behavior Among SCD Patients}

As shown in Table 5, SCD patients who were not enrolled in a health insurance scheme were 18 times more likely to have poor health-seeking behavior $(\mathrm{OR}=18.38$, 95\% CI (4.41-76.57), $\mathrm{p}$ value $=<0.0001)$. Also, the absence of VOC within the preceding year reduces the risk of poor health-seeking behavior among SCD patients by $91.5 \%$ $(\mathrm{OR}=0.085,95 \%$ CI $(0.028-0.258)$, p value $=<0.0001)$. No other determinants/predictors of poor HSB were identified (Table 5).

Table 3 Associated Admissions' Comorbidities/Complications Among the SCD Patients

\begin{tabular}{|l|l|}
\hline Comorbidities & $\begin{array}{l}\text { Number of Patients } \\
\text { Admitted (N=72) n(\%) }\end{array}$ \\
\hline VOC & $5 I(70.8)$ \\
\hline Malaria & $33(45.8)$ \\
\hline Severe anemia & $33(45.8)$ \\
\hline Stroke & $10(13.9)$ \\
\hline Sepsis & $5(6.9)$ \\
\hline Osteomyelitis & $5(6.9)$ \\
\hline Priapism & $3(4.2)$ \\
\hline Infected Leg ulcer & $2(2.8)$ \\
\hline Pneumonia & $2(2.8)$ \\
\hline
\end{tabular}

Note: Some patients had multiple comorbidities/complications. Abbreviation: VOC, vaso-occlusive crisis. 
Table 4 Relationship Between Sociodemographic, Clinical Attributes and Types of Health-Seeking Behavior Among SCD Patients

\begin{tabular}{|c|c|c|c|}
\hline Variables & $\begin{array}{l}\text { Good } \\
\text { Health- } \\
\text { Seeking } \\
\text { Behavior } \\
\text { N=49 n(\%) }\end{array}$ & $\begin{array}{l}\text { Poor Health- } \\
\text { Seeking } \\
\text { Behavior } \\
\text { N=6 I n(\%) }\end{array}$ & P value \\
\hline Sex Male $(N=7 I)$ & $30(61.2)$ & $4 I(67.2)$ & \multirow[t]{2}{*}{$0.376 *$} \\
\hline Female $(\mathrm{N}=39)$ & $19(38.8)$ & $20(32.8)$ & \\
\hline Social class & & & $0.012 *$ \\
\hline Upper $(\mathrm{N}=4)$ & $3(6.2)$ & I (I.6) & \\
\hline Middle $(\mathrm{N}=42)$ & $23(46.9)$ & $19(31.2)$ & \\
\hline Lower $(\mathrm{N}=64)$ & $23(46.9)$ & $4 I(67.2)$ & \\
\hline \multicolumn{3}{|l|}{ NHIS insured } & \multirow[t]{3}{*}{$<0.000 \mathrm{I}^{\dagger}$} \\
\hline Yes $(N=2 I)$ & $16(32.6)$ & $5(8.2)$ & \\
\hline No $(N=89)$ & $33(67.4)$ & $56(91.8)$ & \\
\hline $\begin{array}{l}\text { Admitted within } \\
\text { past I year }\end{array}$ & & & \multirow[t]{3}{*}{$0.53^{*}$} \\
\hline Yes $(N=72)$ & $31(63.3)$ & $41(67.2)$ & \\
\hline No $(N=38)$ & $18(36.7)$ & $20(32.8)$ & \\
\hline $\begin{array}{l}\text { VOC within past } \\
\text { I year }\end{array}$ & & & \multirow[t]{3}{*}{$<0.000$ I* } \\
\hline Yes $(N=5 I)$ & $16(32.6)$ & $35(57.4)$ & \\
\hline No $(N=59)$ & $33(67.4)$ & $26(42.6)$ & \\
\hline
\end{tabular}

Notes: Test statistics $\dagger$ Fisher's exact test, ${ }^{*}$ Chi-Square test. P values in bold fonts indicate statistical significance.

Abbreviations: VOC, vaso-occlusive crisis; NHIS, National Health Insurance Scheme; SCD, sickle cell disease.

\section{Discussion}

The cause and nature of a disease condition as well as local culture, accessibility of affordable orthodox health care and experiences/pieces of advice from locals who have suffered similar disease are factors that tend to influence the health-seeking behavior of the affected individual. In this study, both the SCD and non-SCD patients received treatment outside orthodox care. However, SCD patients were more affected when compared to their non-SCD counterparts. This may be due to the nature of SCD being more frequently associated with recurrent complications. Also, the fact that SCD standard-of-care management is relatively expensive and borne out-of-pocket in our environment may be a factor. ${ }^{29,30}$
Table 5 Binary Logistic Regression for Predictors/Determinants of Poor Health-Seeking Behavior Among SCD Patients

\begin{tabular}{|l|l|l|l|}
\hline Predictor Variables & Odds Ratio & $95 \%$ CI & P value \\
\hline Enrolled on NHIS & 18.384 & $4.414-76.57 I$ & $<0.000$ I \\
\hline NO & & & \\
\hline YES & \multicolumn{5}{|l|}{} \\
\hline Social Class & 1.488 & $0.601-3.683$ & 0.39 \\
\hline Lower & & & \\
\hline Middle and upper & & & \\
\hline VOC within past I year & 0.085 & $0.028-0.258$ & $<0.000$ I \\
\hline NO & \multicolumn{5}{|l}{} \\
\hline YES & 0.720 & $0.289-1.793$ & 0.480 \\
\hline Sex & & \\
\hline Male & Female
\end{tabular}

Note: $P$ values in bold fonts indicate statistical significance.

Abbreviations: $\mathrm{Cl}$, confidence interval; NHIS, National Health Insurance Scheme; $\mathrm{SCD}$, sickle cell disease; VOC, vaso-occlusive crisis.

Patent medicine shops ranked highest among the places where our study participants sought treatment, accounting for $50 \%$ amongst the SCD patients and $32 \%$ amongst the non-SCD patients. The participation of patent medicine vendors (PMV) in healthcare delivery especially in low middle-income countries such as Nigeria is well documented. ${ }^{31-34}$ The implications of this for the care of SCD patients may include delay before presentation at the hospital as the time taken to consult the PMVs and waiting time to see the effect of care provided by the PMVs add up to time taken before presentation at the hospital. In addition, some might have received interventions that could worsen their clinical condition as many of the operators of these PMVs have limited knowledge on the care for SCD patients. It might also add up to the economic burden on the family as some of them who had visited the PMVs might need to still visit the hospitals for the same condition, thus increasing the cost of healthcare with the possibility of tilting them to catastrophic health expenditure..$^{29,30}$

Looking at it from another perspective, the high patronage of PMVs suggests that there is a need to educate and train the operators of the PMVs appropriately on knowing their limitations. Also, the government needs to enforce regulations guiding their operation. 
Our finding of more SCD patients patronizing faithbased centers is supported by finding by previous authors who reported that prayers, herbal medicine and spiritual sources and other mind-body therapies were commonly used healthcare services employed by caregivers of SCD patients and other chronic diseases across Nigeria $^{10,18,24,28,35}$ and other parts of Africa. ${ }^{17,20,36,37}$ These findings may be because of the chronic nature of $\mathrm{SCD}$ and the need for lifelong treatments/repeated visits to the hospital for follow-up hence, the desire for the cure of the disease condition. They may, therefore, seek miracles, at some faith-based centers and other non-orthodox facilities. Furthermore, it may also reflect that many people in Nigeria and some African countries have strong beliefs in religious institutions for healing and healthcare services as previously reported. ${ }^{17,24,28,35}$ This, therefore, suggests the need for community awareness on appropriate care for common clinical manifestations of SCD as some of the people in the community often term children suffering from SCD as afflicted by spirits/devils because of the nature and clinical presentation of SCD and as such, believe that these children need spiritual and other nonorthodox care. Religious leaders may therefore have a role to play in counseling SCD patients with regards to effective care as earlier suggested given their possible prime roles in SCD control in Nigeria. ${ }^{38}$

The observation that more SCD patients received blood transfusion is not surprising given the chronic hemolytic nature of SCD and its commonly associated crises, particularly pain and anemic crises, which often involve the use of several therapeutic approaches including blood transfusion in their management. ${ }^{1-5,39,40}$

Although both groups tended to have an equal rate of therapeutic scarifications at non-orthodox traditional places $(80 \%)$ vs $(83.3 \%)$. Nevertheless, the majority of the 13 participants $8 / 13(62 \%)$ who had scarifications, were SCD patients. The higher preponderance of body scarifications among the SCD patients is not surprising, given that the practice is used by traditional healers to introduce herbs and other substances into different parts of the patient's body through incisions, thus producing scars after healing. These scars are found usually over the limbs and abdomen, which are the common sites of SCD-related pain crisis. Despite the wide acceptability of complementary therapies in the SSA, ${ }^{14}$ some of the practices at these alternative care centres are inimical to health and pose an increased risk of contracting other serious diseases such as human immunodeficiency virus, hepatitis and tetanus that could be transmitted by the use of contaminated instruments. ${ }^{41,42}$ This further suggests the need for more collaboration between the formal sector (orthodox care) and the informal healthcare providers so as to educate the latter group and discourage them from harmful practices to SCD patients and their any other clients. The recent recognition being accorded traditional and complementary medicine in Nigeria is a welcome development and steps taken in the right direction ${ }^{43}$ and should therefore be given all the needed supports.

That the lack of a health insurance predicted poor HSB among the SCD patients is not surprising given the observation by previous authors that the high rate of affordability, ease of access, perceived good healthcare and good response to treatment are key reasons while Nigerians patronize non-orthodox health care. ${ }^{17,28,44}$ These are benefits that clients enrolled in the health insurance scheme are expected to enjoy. Also, most healthcare cost for SCD in Nigeria is usually borne out-of-pocket with the tendency towards financial catastrophe which previous studies have hinted that could push caregivers of SCD patients who are not protected by health insurance to poverty. ${ }^{29,30}$ Therefore, the SCD patients in this study, might have taken advantage of these factors to patronize nonorthodox health care and practiced poor HSB. These observations as found may be a reflection of the roles of poverty in the overall outlook of SCD in Nigeria. ${ }^{45}$

Our findings raise the need for universal health coverage for SCD patients as previously canvased. ${ }^{29,30}$ Doing so will further alleviate the burden of care for the disease and help fulfill the call for more efforts and actions to scale up SCD care in the study location and other parts of the world where the condition is quite prevalent. ${ }^{46}$

Nevertheless, our observation of the association of VOC with poor HSB in this study contrasts with findings by Busari et $\mathrm{al}^{28}$ who observed that VOC did not discriminate regarding whether or not their study participants patronized non-orthodox care in Lagos, Nigeria. Possible explanations for this disparity could stem from the fact that, while their study involved a mixed population of both adults and pediatric age group, ours was purely among the latter group with the likelihood that caregivers of children with SCD in this study could not probably able to bear the repeated sights of seeing their young wards suffering repeated bouts of severe VOC without taking actions to ameliorate their sufferings and such actions could involve seeking help from diverse places. Hence, the possibility of seeking helps from complementary care centres in order to 
find succor for their wards. More so, VOC was the most common reason for which our study participants were hospitalized.

\section{Limitations}

This study is limited by its being both hospital and questionnaire based, with the possibility of recall bias, not totally reflecting the entire community practice. Also, some respondents might not have volunteered the whole information more so, because of the face-to-face contact with the research assistants which could put subtle pressure on the caregivers (respondents). Despite these limitations, the study is the first from the study location and it established that the health-seeking behavior for children with SCD was suboptimal and proposed several possibilities for the findings as well as suggesting some approaches towards addressing the situation.

\section{Conclusion}

This study revealed that the majority of SCD patients in our study locality exhibited poor HSB by seeking care from non-hospital and unorthodox sources including patent medicine shops, faith-based centers and traditional healers. Some practices at these places included the use of scarifications and other non-orthodox care methods which have huge implications for grave health consequences. Guardians of SCD patients need to be made aware of the risks associated with poor HSB so as to discourage such a practice. More enrollment into health insurance scheme and the prevention of VOC will lessen the burden of poor HSB among SCD patients. Finally, there is a need to recognize other non-orthodox care facilities in the study locality and possibly, most parts of the SSA in order to allow for policy makers and stakeholders to train and monitor their activities for effective healthcare delivery.

\section{Abbreviations}

SCD, sickle cell disease; HSB, health-seeking behavior; VOC, vaso-occlusive crisis; PMV, patent medicine vendor.

\section{Ethical Approval}

This study was performed according to the Declaration of Helsinki on research involving human subjects. Ethical approval was obtained from the Ethics and Research Committee of the EKSUTH and written informed consent was obtained from the guardians/parents of the children (patients and controls) as well as patients' assents where applicable and they were assured of the confidentiality of their responses. Data were stored on a computer after personal identifiers had been removed and were only accessible to the research team with a password.

\section{Acknowledgment}

The authors acknowledge with thanks the supports received from the parents during the study.

\section{Author Contributions}

All authors made substantial contributions to conception and design, acquisition of data, or analysis and interpretation of data; took part in drafting the article or revising it critically for important intellectual content; agreed to submit to the current journal; gave final approval of the version to be published; and agree to be accountable for all aspects of the work.

\section{Funding}

The study was self-sponsored.

\section{Disclosure}

The authors declare no conflicts of interest with respect to this study.

\section{References}

1. Charkravorty S, Williams TN. Sickle cell disease: a neglected chronic disease of increasing global health importance. Arch Dis Child. 2015;100:48-53. doi:10.1136/archdischild-2013-303773

2. Galadanci N, Wudil BJ, Balogun TM, et al. Current sickle cell disease management practices in Nigeria. Int Health. 2014;6:23-28. doi:10.1093/inthealth/iht022

3. Piel FB, Patil AP, Howes RE, et al. Global epidemiology of sickle haemoglobin in neonates: a contemporary geostatistical model-based map and population estimates. Lancet. 2013;381:142-151. doi:10.1016/S0140-6736(12)61229-X

4. Adekile AD. What's new in the pathophysiology of sickle cell disease. Med Princ Pract. 2013;22:311-312.

5. Piel FB, Steinberg MH, Rees DC. Sickle cell disease. $N$ Engl J Med. 2017;376:1561-1573. doi:10.1056/NEJMra1510865

6. Piccin A, Fleming P, Eakins E, McGovern E, Smith OP, McMahon C. Sickle cell disease and dental treatment. $J$ Ir Dent Assoc. 2008;54:75-79.

7. Piccin A, Murphy C, Eakins E, et al. Insight into the complex pathophysiology of sickle cell anaemia and possible treatment. Eur J Haematol. 2019;102:319-330. doi:10.1111/ejh.13212

8. Diaku-Akinwumi IN, Abubakar SB, Adegoke SA, et al. Blood transfusion services for patients with sickle cell disease in Nigeria. Int Health. 2016;8(5):330-335. doi:10.1093/inthealth/ihw014

9. Wade DT, Halligan PW. Do biomedical models of illness make for good health care system. BMJ. 2004;329:1398-1401. doi:10.1136/ bmj.329.7479.1398

10. Afolabi MO, Daropale VO, Irinoye AI, Adegoke AA. Health seeking behavior and student perception of health care services in a university community in Nigeria. Health. 2013;5:817-824. doi:10.4236/ health.2013.55108 
11. Siddiqui MS, Siddiqui MK, Sohage AA. Health seeking behavior of the people; knowledge, attitudes and practices(KAP) study of the people of urban slum Areas of Karachi. Prof Med J. 2011;18:626-631.

12. Oberoi S, Chaudhary N, Patnack S, Singh A. Understanding health seeking behavior. J Family Med Prim Care. 2016;5:463-464. doi:10.4103/2249-4863.192376

13. Shaikh BT, Hatcher J. Health seeking behavior \& health service utilization in Pakistan: challenging the policy makers. $J$ Public Health (Bangkok). 2004;27:49-54. doi:10.1093/pubmed/fdh207

14. Zhang T, Liu X, Bromley H, Tang S. Perceptions of tuberculosis and health seeking behavior in rural Inner Mongolia, China. Health Policy. 2007;81:155-165. doi:10.1016/j.healthpol.2005.12.009

15. Munthali A, Braathen SH, Grut L, Kamaleri Y, Ingstad B. Seeking care for epilepsy and its impact on households in a rural district in southern Malawi. Af J Disabil. 2013;2:54. doi:10.4102/ajod.v2i1.54

16. EhsanulHuq KATM, Moriyama M, Zaman K, et al. Health seeking bahaviour and delayed management of tuberculosis patients in rural Bangladesh. BMC Infect Dis. 2018;18:515. doi:10.1186/s12879-0183430-0

17. James PB, Wardle J, Steel A, Adam J. Traditional, complementary and alternate medicine use in sub-Saharan Africa: a systematic review. BMJ Global Health. 2018;3:e00895. doi:10.1136/bmjgh2018-000895

18. Ojinnaka CN, Aronu AE, Ojinnaka GC, Uwaezuoke NA, BisiOnyemaechi AJ. Health seeking behavior of care-givers of children with epilepsy in a resource poor country. Acta Sci Neurol. 2019;2.

19. Famuyiwa OO, Aina OF. Mother's knowledge of sickle cell anaemia in Nigeria. Int $Q$ Community Health Educ. 2010;30:69-80. doi:10.2190/IQ.30.1.f

20. Sinkala D, Fleming LC, Silwimba F, Jacobsen KH. Health services access for young children with sickle cell anaemia in the chilubi District of Zambia. Med J Zambia. 2018;45:133-137.

21. Olatunya OS, Albuquerque DM, Adekile AD, Costa FF. Evaluation of sociodemographic, clinical, and laboratory markers of sickle leg ulcers among young nigerians at a Tertiary Health Institution. Niger J Clin Pract. 2018;21:882-887. doi:10.4103/njcp.njcp_4_18

22. Hajian-Tilaki K. Sample size estimation in epidemiologic studies. Caspian J Intern Med. 2011;2(4):289-298.

23. Lagunju IA. Complementary and alternative medicines use in children with epilepsy in Ibadan, Nigeria. Afr $J$ Med Med Sci. 2013;42:15-23.

24. Oshikoya Oshikoya KA, Senbanjo IO, Njokanma OF, Soipe A. Use of complementary and alternative medicines for children with chronic health conditions in Lagos, Nigeria. BMC Complement Altern Med. 2008;8:66. doi:10.1186/1472-6882-8-66

25. Kirkwood BR, Sterne JAC. Calculating the Required Sample Size. Essential Medical Statistics. 2nd ed. Massachusetts: Blackwell science; 2003:413-428.

26. Olatunya OS, Albuquerque DM, Santos MNN, Kayode TS, Adekile A, Costa FF. Haptoglobin gene polymorphism in patients with sickle cell anemia: findings from a Nigerian Cohort Study. Appl Clin Genet. 2020;13:107-114. doi:10.2147/TACG.S246607

27. Oyedeji GA. Socio-economic and cultural background of hospitalised children in Ilesha. Niger J Paediatr. 1985;12(4):111-117.

28. Busari AA, Mufutau MA. High prevalence of complementary and alternative medicine use among patients with sickle cell disease in a tertiary hospital in Lagos, South West, Nigeria. BMC Complement Altern Med. 2017;17:299. doi:10.1186/s12906-017-1812-2

29. Brown BJ, Okereke JO, Lagunju IA, Orimadegun AE, Ohaeri JU, Akinyinka OO. Burden of health-care on carers of children with sickle cell disease in Nigeria. Health Soc Care Community. 2010;18 (3):289-295. doi:10.1111/j.1365-2524.2009.00903.x
30. Olatunya OS, Ogundare EO, Fadare JO, et al. The financial burden of sickle cell disease on households in Ekiti, Southwest Nigeria. Clinicoecon Outcomes Res. 2015;7:545-553. doi:10.2147/CEOR. S86599

31. Prach LM, Treleaven E, Isiguzo C, Liu J. Care seeking at patent and proprietary medicine vendors in Nigeria. BMC Health Serv Res. 2015;15:231. doi:10.1186/s12913-015-0895-z

32. Liu J, Prach LM, Treleaven E, et al. The role of drug vendors in improving basic health care services in Nigeria. Bull World Health Organ. 2016;94:267-275. doi:10.2471/BLT.15.154666

33. Onwujekwe O, Chukwuogo O, Ezeoke U, Uzochukwu B, Eze S. Asking people directly about preferred health seeking behavior yields invalid response: an experiment in south east Nigeria. $J$ Public Health (Bangkok). 2011;33:93-100. doi:10.1093/pubmed/fdq065

34. Chirdan OO, Zoakah AI, Ejembi CL. Impact of health education on home treatment and prevention of malaria in Jengre, north central Nigeria. Ann Afr Med. 2008;7:112-119. doi:10.4103/15963519.55667

35. Gideon OO, Chioma AP. Indigenous complimentary health seeking behavior among caregivers of sickle cell disorder in Nigeria. $J$ Genet Disor Genet Rep. 2015;4:2. doi:10.4172/2327-5790.1000126

36. Nnko S, Bukenya D, Kavishe BB, et al. Chronic diseases in North-west Tanzania and Southern Uganda: public perceptions of terminologies, aetiologies, symptoms and preferred management. PLoS One. 2015;10(11):e0142194. doi:10.1371/journal. pone. 0142194

37. Tusuubira SK, Nakayinga R, Mwambi B, Odda J, Kiconco S, Komuhangi A. Knowledge, perception and practices towards sickle cell disease: a community survey among adults in Lubaga division, Kampala, Uganda. BMC Public Health. 2018;18:561. doi:10.1186/ s12889-018-5496-4

38. Olatunya OS, Babatola AO, Ogundare EO, et al. Perceptions and practice of early diagnosis of sickle cell disease by parents and physicians in a southwestern state of Nigeria. World Sci J. 2020;2020:4801087. doi:10.1155/2020/4801087

39. Diwe KC, Iwu AC, Uwakwe K, et al. prevalence and pattern of sickle cell disease among children attending tertiary and non tertiary health care institutions in a south Eastern state, Nigeria: a 10 year survey. $J$ Res Med Dent Sci. 2016;4(3):75-81. doi:10.5455/jrmds.2016432

40. Saganuwan AS. The pattern of sickle cell disease patients from Northwestern Nigeria. Clin Med Insights Ther. 2016;8:53-57. doi:10.4137/CMT.S38164

41. Garve R, Garve M, Turp JC, Fobil JN, Meyer CG. Scarification in sub-Saharan Africa: social skin, remedy and medical import. Trop Med Int Health. 2017;22(6):708-715. doi:10.1111/tmi.12878

42. Hrdy DB. Cultural practices contributing to the transmission of human immunodeficiency virus in Africa. Rev Infect Dis. 1987;9 (6):1109-1119. doi:10.1093/clinids/9.6.1109

43. Lawal S Nigeria government takes steps to promote alternative medicine. 2019. Available from: https://allafrica.com/stories/ 201912060178.html. Accessed November 26, 2020.

44. Aina O, Gautam L, Simkhada P, Hall S. Prevalence, determinants and knowledge about herbal medicine and non-hospital utilisation in southwest Nigeria: a cross-sectional study. BMJ Open. 2020;10: e040769. doi:10.1136/bmjopen-2020-040769

45. Olatunya OS. Poverty and severity of childhood sickle cell disease. Br J Haematol. 2020;190(6):819-821. doi:10.1111/bjh.16816

46. Ware RE. Is sickle cell anemia a neglected tropical disease? PLoS Negl Trop Dis. 2013;7(5):e2120. doi:10.1371/journal.pntd.0002120 


\section{Publish your work in this journal}

The Journal of Blood Medicine is an international, peer-reviewed, open access, online journal publishing laboratory, experimental and clinical aspects of all aspect pertaining to blood based medicine including but not limited to: Transfusion Medicine; Blood collection, Donor issues, Transmittable diseases, and Blood banking logistics; Immunohematology; Artificial and alternative blood based therapeutics; Hematology; Biotechnology/nanotechnology of blood related medicine; Legal aspects of blood medicine; Historical perspectives. The manuscript management system is completely online and includes a very quick and fair peer-review system. Visit http://www.dovepress.com/testimonials.php to read real quotes from published authors. 